\title{
Volwasseneneducatie : een inventarisatie van bestaande databestanden
}

Citation for published version (APA):

van der Velden, R. K. W., \& Willems, E. J. T. A. (1991). Volwasseneneducatie : een inventarisatie van bestaande databestanden. Researchcentrum voor Onderwijs en Arbeidsmarkt, Faculteit der Economische Wetenschappen. ROA Working Papers No. 4 https://doi.org/10.26481/umarow.1991004

Document status and date:

Published: 01/01/1991

DOI:

10.26481/umarow.1991004

Document Version:

Publisher's PDF, also known as Version of record

\section{Please check the document version of this publication:}

- A submitted manuscript is the version of the article upon submission and before peer-review. There can be important differences between the submitted version and the official published version of record.

People interested in the research are advised to contact the author for the final version of the publication, or visit the DOI to the publisher's website.

- The final author version and the galley proof are versions of the publication after peer review.

- The final published version features the final layout of the paper including the volume, issue and page numbers.

Link to publication

\footnotetext{
General rights rights.

- You may freely distribute the URL identifying the publication in the public portal. please follow below link for the End User Agreement:

www.umlib.nl/taverne-license

Take down policy

If you believe that this document breaches copyright please contact us at:

repository@maastrichtuniversity.nl

providing details and we will investigate your claim.
}

Copyright and moral rights for the publications made accessible in the public portal are retained by the authors and/or other copyright owners and it is a condition of accessing publications that users recognise and abide by the legal requirements associated with these

- Users may download and print one copy of any publication from the public portal for the purpose of private study or research.

- You may not further distribute the material or use it for any profit-making activity or commercial gain

If the publication is distributed under the terms of Article $25 \mathrm{fa}$ of the Dutch Copyright Act, indicated by the "Taverne" license above, 


\section{VOLWASSENENEDUCATIE EEN INVENTARISATIE VAN BESTAANDE \\ DATABESTANDEN}

ROA-W-1991/4

R.K.W. van der Velden, E.J.T.A. Willems

RESEARCHCENTRUM VOOR ONDERWIJS EN ARBEIDSMARKT

Faculteit der Economische Wetenschappen

Rijksuniversiteit Limburg

Maastricht, mei 1991 


\section{CIP-GEGEVENS KONINKLIJKE BIBLIOTHEEK, DEN HAAG}

Velden, R.K.W. van der

Volwasseneneducatie: een inventarisatie van bestaande databestanden / R.K.W. van der Velden, E.J.T.A. Willems. - Maastricht: Researchcentrum voor Onderwijs en Arbeidsmarkt, Faculteit der Economische Wetenschappen, Rijksuniversiteit Limburg - (ROA-W-1991/4) ISBN 90-5321-073-3 in spiraalband

Trefw.: volwasseneneducatie; databanken. 


\section{INHOUDSOPGAVE}

\section{Bladzijde}

1. INLEIDING

2. INVENTARISATIE VAN BESTAANDE BESTANDEN

2.1. Data verzameld op instellingsniveau

2.2. Data verzameld op bedrijfsniveau

2.3. Data verzameld op individueel niveau

3. NABESCHOUWING EN CONCLUSIES

BIJLAGE: LIJST MET GERAADPLEEGDE INSTANTIES 


\section{INLEIDING}

De deelname aan de volwasseneneducatie staat de laatste tijd nogal in de belangstelling. Er kan een onderscheid worden gemaakt tussen verschillende vormen van volwasseneneducatie, variërend van de basiseducatie en cursussen in de hobbysfeer tot deeltijd-opleidingen op wetenschappelijk niveau. Ook kan een groot aantal beroepsgerichte opleidingen worden beschouwd. Een voorbeeld hiervan zijn de bedrijfsopleidingen.

Met het doel meer zicht te krijgen op de bestaande databestanden met betrekking tot de volwasseneneducatie heeft de Raad voor de Volwasseneneducatie (RVE) namens het Ministerie van Onderwijs en Wetenschappen het Researchcentrum voor Onderwijs en Arbeidsmarkt (ROA) verzocht een inventarisatie te verrichten. De vraagstelling was daarbij als volgt:

"Welke structurele en incidentele databestanden zijn er in de periode van 1986 tot en met 1990 opgebouwd, waarin variabelen voorkomen die eventueel bruikbaar zouden kunnen zijn voor het verrichten van secundaire analyses naar de werking en het functioneren van de volwasseneneducatie-markt in Nederland?"

De methode van onderzoek bestond uit het (veelal telefonisch) benaderen van diverse onderzoeksinstituten en andere instellingen, zoals bijvoorbeeld het Centraal Bureau voor de Statistiek ${ }^{1}$. Bovendien is op grond van een klein literatuuronderzoek informatie over een aantal databestanden verkregen. Het onderzoek is uitgevoerd door drs. R.K.W. van der Velden (projectleider) en drs. E.J.T.A. Willems, daarbij geassisteerd door M.E.C. Reiners.

Met behulp van de verkregen informatie is een overzicht gemaakt van de belangrijkste databestanden met betrekking tot volwasseneneducatie. Daarbij is een onderscheid gemaakt tussen data die zijn verzameld op instellingsniveau, op bedrijfsniveau en op individueel niveau. Deze data worden kort besproken in respectievelijk de paragrafen 2.1. tot en met 2.3. Bij de beschrijving wordt ingegaan op vragen als 'Wie beheert het bestand?' en 'Is het bestand beschikbaar voor onderzoeksdoeleinden?' Ook wordt aangegeven op welke populatie (doelgroep) de gegevens betrekking hebben en wat de steekproefomvang is. Vervolgens wordt kort iets over de aard van het bestand vermeld en wordt ingegaan op de variabelen in het bestand. Daarbij wordt een onderscheid gemaakt tussen variabelen met betrekking tot volwasseneneducatie en achtergrondvariabelen. Tenslotte is vaak een (basis-)publikatie vermeld, waarin het bestand en/of de belangrijkste resultaten worden beschreven. Overigens moet worden vermeld dat niet is gestreefd naar een volledig overzicht van de bestaande bestanden. In hoofdstuk 3 wordt op basis van de verzamelde informatie over de databestanden een

1. Een overzicht van de benaderde instanties is gegeven in de bijlage. 
nabeschouwing gehouden. Daarbij wordt ingegaan op een groot aantal onderzoeksvragen die op verschillende analyseniveaus betrekking kunnen hebben, te weten:

- $\quad$ individueel niveau;

- organisatieniveau;

- opleidingsniveau;

- (deel-)marktniveau;

- macro-niveau.

Voor alle onderscheiden niveaus worden de mogelijke onderzoeksvragen ingedeeld in een drietal categorieën, namelijk vragen betreffende de scholingsbehoefte en de feitelijke deelname aan scholing, de kosten of het intern rendement van scholing en de effecten van scholing. Tenslotte wordt in dit hoofdstuk aangegeven of de beschreven databestanden toereikend zijn om de gestelde onderzoeksvragen te kunnen beantwoorden. 


\section{INVENTARISATIE VAN BESTAANDE BESTANDEN}

\subsection{Data verzameld op instellingsniveau}

Het Centraal Bureau voor de Statistiek verzamelt een groot aantal gegevens over de deelnemersaantallen aan diverse vormen van volwasseneneducatie. Recentelijk is daarvan een overzicht gemaakt ${ }^{2}$. In dit overzicht wordt een twaalftal vormen van volwasseneneducatie besproken. Ook door RVE Adviescentrum Volwasseneneducatie is onlangs een overzicht gemaakt van deelname aan en uitgaven voor volwasseneneducatie ${ }^{3}$. In deze paragraaf zal slechts aandacht worden besteed aan de CBS-statistieken betreffende het regulier deeltijdonderwijs. Andere databestanden die kunnen worden genoemd betreffen bijvoorbeeld de basiseducatie, het vormings- en ontwikkelingswerk, het leerlingwezen, het particulier onderwijs en het Teleac-onderwijs. Ook de bestanden met deelnemersgegevens aan de scholingsmaatregelen van het Ministerie van Sociale Zaken en Werkgelegenheid (Arbeidsvoorziening) kunnen in dit verband worden genoemd.

\section{Regulier deeltijdonderwijs}

Beheer: $\quad$ Centraal Bureau voor de Statistiek, hoofdafdeling statistieken van onderwijs en wetenschappen, Voorburg

Toegankelijkheid: In principe beschikbaar, in overleg met CBS

Doelgroep: $\quad$ Alle deelnemers regulier deeltijdonderwijs

Steekproef: $\quad$ Alle deelnemers regulier deeltijdonderwijs

Korte beschrijving van het bestand:

Via de diverse instellingen worden reeds vele jaren per opleidingsniveau en -richting de gegevens verzameld over het aantal deelnemers aan het reguliere deeltijdonderwijs. De meeste gegevens zijn gedifferentieerd naar leeftijd, geslacht, nationaliteit en regio.

Publikaties:

Dit betreft de jaarlijkse CBS-publikaties Statistiek van het vwo, havo en mavo; scholen en leerlingen, Statistiek van het lager beroepsonderwijs; scholen en leerlingen, Statistiek van het middelbaar beroepsonderwijs; scholen en leerlingen, Statistiek van het hoger beroepsonderwijs en Statistiek van het wetenschappelijk onderwijs.

2. Centraal Bureau voor de Statistiek (1990), Volwasseneneducatie, statistisch overzicht 1988, SDU/Uitgeverij, 's-Gravenhage.

3. Cramer, G., M. van der Kamp (1991), Feiten en cijfers over de volwasseneneducatie; Trends in de periode 1979-1988, RVE, Utrecht. 


\subsection{Data verzameld op bedrijfsniveau}

In deze paragraaf komen achtereenvolgens de volgende databestanden aan de orde:

- Bedrijfsopleidingen in Nederland 1986;

- $\quad$ OSA arbeidsvraagsurvey 1989.

Bedrijfsopleidingen in Nederland 1986

Beheer: $\quad$ Centraal Bureau voor de Statistiek, hoofdafdeling statistieken van onderwijs en wetenschappen, Voorburg

Toegankelijkheid: In overleg met CBS

Doelgroep: Bedrijven met 5 of meer werknemers, excl. overheid, religieuze instellingen, gezondheidszorg en onderwijs

Steekproef: Ongeveer 5.000 bedrijven

Korte beschrijving van het bestand:

Met behulp van een voorenquête onder een steekproef van 24.000 bedrijven uit een populatie van 73.000 is opgespoord welke bedrijven actief zijn op het gebied van bedrijfsopleidingen, d.w.z. het verzorgen van interne opleidingen en/of de mogelijkheid bieden dat werknemers extern opleidingen volgen. Vervolgens is een uitgebreide enquête gehouden onder de bedrijven die inderdaad op dit gebied actief zijn. In de loop van 1991 wordt het onderzoek herhaald.

Variabelen met betrekking tot volwasseneneducatie:

Aan de geënquêteerde bedrijven is gevraagd hoeveel medewerkers in 1986 hebben deelgenomen aan interne en/of externe cursussen. Van deze cursussen is dan het doel, de duur, de opleidingsrichting en het vereiste niveau van vooropleiding bekend. Bovendien wordt gevraagd naar de faciliteiten die het bedrijf biedt en de totale kosten die daarmee zijn gemoeid.

\section{Achtergrondvariabelen:}

De belangrijkste achtergrondvariabele op bedrijfsniveau is het aantal werknemers die bij het bedrijf in dienst zijn. Van de cursusdeelnemers is het geslacht en de arbeidsduur (voltijd of deeltijd) bekend.

\section{Publikaties:}

Centraal Bureau voor de Statistiek (1988), Bedrijfsopleidingen in Nederland 1986, Staats uitgeverij, 's-Gravenhage.

Mulder, M., J.S. Akkermans, N. Bentvelsen (1988), Bedrijfsopleidingen in Nederland, 'sGravenhage. 
Beheer: Stichting Organisatie voor Strategisch Arbeidsmarktonderzoek, 's-Gravenhage Toegankelijkheid: In principe niet beschikbaar

Doelgroep: Zelfstandige organisaties met meer dan 10 werknemers

Steekproef: Ongeveer 2.000 bedrijven

Korte beschrijving van het bestand:

Het OSA-arbeidsvraagsurvey heeft in principe een panelkarakter, waarvan in 1989 de eerste ronde is gehouden.

Variabelen met betrekking tot volwasseneneducatie:

Aan de responderende bedrijven is gevraagd welk deel van hun werknemers heeft deelgenomen aan bedrijfsinterne en/of externe opleidingen of cursussen. Van deze opleidingen is het niveau en de richting bekend. Bovendien is de duur van de opleidingen bekend.

\section{Achtergrondvariabelen:}

Van de bedrijven is een aantal kenmerken bekend, zoals de bedrijfssector en de bedrijfsgrootte. Ook is een aantal kenmerken van de werknemers van de bedrijven bekend. Voorbeelden daarvan zijn de leeftijdsopbouw, het percentage vrouwelijke werknemers en het gemiddelde scholingsniveau van de personeelsleden. Naast een aantal andere achtergrondvariabelen zijn bijvoorbeeld ook gegevens beschikbaar over het aantal vacatures en of deze al dan niet moeilijk vervulbaar zijn.

Publikatie:

Allaart, P.C., R. Kunnen, H.A. van Stiphout (1990), Trendrapport Vraag naar arbeid 1990, OSArapport $\mathrm{nr} .11$, 's-Gravenhage.

\subsection{Data verzameld op individueel niveau}

Hoewel de in deze paragraaf te bespreken data alle individuele gegevens betreffen, bestaat er een verschil in het karakter van de diverse bestanden. In de eerste plaats zijn er databestanden die via de instellingen voor volwasseneneducatie zijn verzameld. In deze rapportage worden achtereenvolgens besproken:

- Cursusdeelnemers Open Universiteit;

- Landelijke gegevens Primaire Beroepsgerichte Volwasseneneducatie (PBVE).

Daarna wordt een zevental databestanden besproken, waarbij de gegevens zijn verkregen door middel van enquêtering van de inviduen of huishoudens. Daarbij kan worden opgemerkt dat bij 
de laatste vier bestanden de doelgroep slechts beperkt is. De beschreven bestanden zijn:

- Enquête Beroepsbevolking (EBB);

- Tijdsbestedingsonderzoek (TBO);

- Algemeen Voorzieningengebruik Onderzoek (AVO);

- $\quad$ Project Intensivering Bijscholing (PIB);

- Bestanden evaluatie scholingsmaatregelen;

- Project Onderwijs, Scholing en Arbeidsmarkt in de Metaalnijverheid (OSAM);

- Longitudinaal Onderzoek Werknemers Bouw.

Tenslotte wordt een drietal bestanden besproken, die een longitudinaal ${ }^{4}$ of panelkarakter hebben:

- $\quad$ OSA arbeidsaanbodsurvey 1988;

- Brabant-survey;

- Van jaar tot jaar.

\section{Cursusdeelnemers Open Universiteit}

Beheer: $\quad$ Open Universiteit, Bureau Examens en Inschrijving, Heerlen

Toegankelijkheid: In overleg

Doelgroep: Alle cursusdeelnemers Open Universiteit

Steekproef: $\quad$ Alle cursusdeelnemers Open Universiteit

Korte beschrijving van het bestand:

Het bestand betreft alle (circa 100.000) ingeschrevenen aan de Open Universiteit, waarvan permanent een aantal gegevens worden geadministreerd. De persoonsgegevens zijn daarbij verzameld met behulp van de inschrijvingsformulieren die de studenten invullen. De cursusgegevens worden direct door de Open Universiteit bijgehouden.

Variabelen met betrekking tot volwasseneneducatie:

Van de gevolgde cursussen is naast de opleidingsrichting de datum van aanmelding (begindatum), behaalde tentamenresultaten en de einddatum bekend. Deze einddatum kan de datum van slagen dan wel het verlopen van de inschrijftermijn betreffen.

Achtergrondvariabelen:

Van de cursisten is o.a. de leeftijd, het geslacht en de vooropleiding bekend. Tevens is informatie beschikbaar over de motivatie tot cursusdeelname. De arbeidsmarktinformatie betreft

4. Het Longitudinaal Onderzoek Werknemers Bouw heeft vanaf 1990 geen panelkarakter meer. Daarom is dit bestand bij de individuele gegevens genoemd. 
met name het al dan niet hebben van een betaalde werkkring en zo ja, het aantal uren dat men werkt en het beroep en de bedrijfstak waarin men actief is.

Publikatie:

Joosten, G. (1990), Studenten: algemene kenmerken, inschrijving naar studiecentrum, leerstof gebied en cursus tot 1 januari 1990, Open Universiteit, Studentenstatistiek rapport 14, Heerlen.

Landelijke gegevens Primaire Beroepsgerichte Volwasseneneducatie (PBVE)

Beheer: Bureau Berenschot, Utrecht

Toegankelijkheid: Beschikbaar voor onderzoeksdoeleinden

Doelgroep: Alle deelnemers aan de PBVE

Steekproef: $\quad$ Alle deelnemers aan de PBVE

Korte beschrijving van het bestand:

leder kwartaal worden gegevens verzameld van de (ongeveer 18.000) deelnemers van de Primaire Beroepsgerichte Volwasseneneducatie (PBVE). Vanaf 1 oktober 1990 betreft dit gegevens op cursistenniveau. De gegevens worden echter door de PBVE-instellingen verzameld, waarna een centrale registratie plaats vindt door Bureau Berenschot. Dit bureau heeft als intermediair PBVE een rol als informatieverschaffer.

Variabelen met betrekking tot volwasseneneducatie:

Van de deelnemers aan de PBVE is de sector van scholing van de gevolgde cursus bekend. Bovendien wordt de reden van uitstroom uit de PBVE geadministreerd (bijvoorbeeld halverwege de cursus gestopt, diploma behaald, werk gevonden e.d.).

Achtergrondvariabelen:

Van de deelnemers is een aantal gegevens bekend, zoals het geslacht, de leeftijd en de genoten vooropleiding. Tevens is een aantal arbeidsmarktgegevens beschikbaar, bijvoorbeeld of men is ingeschreven bij een Gewestelijk Arbeidsbureau en of men al dan niet 'bemiddelbaar' is.

Publikatie:

Berenschot (1991), Kwartaalrapportage TRIS/PBVE per 1 oktober 1990 (tabellen en grafieken), Utrecht. 
Beheer: $\quad$ Centraal Bureau voor de Statistiek, hoofdafdeling statistieken van arbeid en lonen

Toegankelijkheid: In overleg met CBS

Doelgroep: Personen woonachtig in Nederland met uitzondering van personen in inrichtingen, instellingen en tehuizen

Steekproef: $\quad$ Circa 132.000 huishoudens per jaar

Korte beschrijving van het bestand:

De Enquête Beroepsbevolking (EBB) is een doorlopende enquête, die is gestart in januari $1987^{5}$. De gegevens worden vervolgens per jaar verzameld. In de EBB's tot 1989 zijn vooralsnog geen gegevens over opleidingen opgenomen. Deze informatie wordt wel gevraagd in de EBB, maar is nog niet geschikt voor publikatie. Dit houdt tevens in dat er nog geen variabelen met betrekking tot de volwasseneneducatie in de thans beschikbare gegevens zijn opgenomen. Waarschijnlijk zullen vanaf de EBB 1990 echter wel opleidingsgegevens beschikbaar zijn.

Variabelen met betrekking tot volwasseneneducatie:

In de EBB wordt gevraagd of de respondenten op het moment van enquête aan een cursus deelnemen, en zo ja, wat voor soort cursus dit is en waar deze wordt gevolgd (school, in het bedrijf, schriftelijke cursus e.d.). Ook wordt gevraagd wat het doel van de gevolgde cursus is (bijvoorbeeld: "in verband met huidige werkkring").

Achtergrondvariabelen:

De EBB bevat een groot aantal arbeidsmarktvariabelen, zoals beroep, bedrijfssector, arbeidsduur, werkend of niet-werkend (werkzoekend, niet beschikbaar voor de arbeidsmarkt). Voorts wordt een groot aantal opleidingsgegevens gevraagd. Ook zijn van de respondenten onder andere het geslacht, de leeftijd en de burgerlijke staat bekend.

Publikatie:

Centraal Bureau voor de Statistiek (1990), Enquête Beroepsbevolking 1989, Voorburg/Heerlen.

5. De EBB is de opvolger van de Arbeidskrachtentelling, welke tweejaarlijks is gehouden van 1973 tot 1985. 
Beheer: AGB-Intomart

Toegankelijkheid: Na ongeveer 2,5 jaar via het Steinmetz-archief ${ }^{6}$

Doelgroep: Nederlanders van 12 jaar en ouder

Steekproef: Ongeveer 3.000 personen

Korte beschrijving van het bestand:

In de jaren 1975, 1980, 1985 en 1990 is aan een steekproef uit de Nederlandse bevolking een groot aantal vragen over hun dagelijkse bezigheden en hun achtergronden gesteld. Het onderzoek van 1990 is nog niet afgerond.

Variabelen met betrekking tot volwasseneneducatie:

Aan de deelnemers aan de enquête is gevraagd of zij (behalve het dagonderwijs) nog cursussen of opleidingen hebben gevolgd of nog volgen. Van deze cursussen is, naast de aard van de cursus, de einddatum (jaar) en de plaats waar deze is gevolgd (bijvoorbeeld via bedrijf, schriftelijk onderwijs, Teleac e.d.) bekend. Ook is bekend of men de gevolgde cursussen heeft afgemaakt, voortijdig heeft afgebroken of dat men nog met de cursus bezig is.

Achtergrondvariabelen:

Van de respondenten is een groot aantal achtergrondvariabelen bekend. Naast de gebruikelijke persoonsgegevens betreft dit hun dagelijkse bezigheden, waaronder bijvoorbeeld hun werkkring.

Publikaties:

Bronneman-Helmers, R. (1988), Samenhang rond volwasseneneducatie, Sociaal en Cultureel Planbureau, Stukwerk nr. 47, Rijswijk.

Knulst, W.P., P. van Beek (1989), Tijd komt met de jaren; Onderzoek naar tegenstellingen en veranderingen in dagelijkse bezigheden van Nederlanders op basis van tijdbudgetonderzoek, Sociaal en Cultureel Planbureau, Sociale en Culturele Studie nr. 14, Rijswijk.

Aanvullend Voorzieningengebruik Onderzoek (AVO)

Beheer: Centraal Bureau voor de Statistiek, Voorburg; Sociaal en Cultureel Planbureau, Rijswijk

Toegankelijkheid: $\mathrm{Na}$ ongeveer 2 jaar via het Steinmetz-archief

6. Het Steinmetz-archief is een afdeling van het Sociaal-Wetenschappelijk Informatie- en Documentatiecentrum (SWIDOC), gevestigd te Amsterdam. In dit archief zijn tal van Nederlandse databestanden met betrekking tot sociaal-wetenschappelijk onderzoek opgeslagen. 
Doelgroep: Jongeren 6-15 jaar en volwassenen ouder dan 15 jaar

Steekproef: $\quad$ Ruim 6.000 huishoudens en ruim 16.000 personen binnen die huishoudens

Korte beschrijving van het bestand:

Het onderzoek heeft tot doel inzicht te verkrijgen in het gebruik van een groot aantal voorzieningen door de Nederlandse bevolking. Tot nu toe is het AVO drie keer gehouden, namelijk in 1979, 1983 en 1987, in opdracht van het SCP en uitgevoerd door de NSS.

Variabelen met betrekking tot volwasseneneducatie:

De respondenten is gevraagd of zij aan part-time onderwijs deelnemen. Van de gevolgde cursussen is de aard (avondonderwijs, bedrijfscursus, schriftelijk onderwijs, e.d.) bekend. Ook het niveau van de cursussen is bekend.

\section{Achtergrondvariabelen:}

Dit betreft de gebruikelijke achtergrondvariabelen als leeftijd, geslacht en het niveau van de vooropleiding. Ook is het beroep van de respondenten bekend. Daarnaast is informatie beschikbaar over het al dan niet gebruiken van een aantal andere voorzieningen bekend, zoals bijvoorbeeld medische voorzieningen en het lidmaatschap van verenigingen.

Publikatie:

Klaassen, I., C. Jol (1988), Aanvullend Voorzieningengebruik Onderzoek 1987; kerncijfers, Sociaal-Culturele Berichten 88-12, Centraal Bureau voor de Statistiek, Voorburg.

\section{Project Intensivering Bijscholing (PIB)}

Beheer: $\quad$ Bureau Bartels BV

Toegankelijkheid: Niet beschikbaar

Doelgroep: $\quad$ Alle geschoolde werknemers binnen het PIB-project

Steekproef: Ongeveer 1.000 personen

Korte beschrijving van het bestand:

In opdracht van het Ministerie van Sociale Zaken en Werkgelegenheid en het Ministerie van Economische Zaken verzamelt Bureau Bartels doorlopend tot en met 1991 een aantal gegevens van de deelnemers van het PIB-project. Dit project heeft betrekking op de drie noordelijke provincies.

Variabelen met betrekking tot volwasseneneducatie:

De respondenten wordt onder andere gevraagd wat de motivatie voor en het verwachte effect 
van de te volgen bijscholing is. Bovendien wordt nagegaan wat men vindt van het opleidingsbeleid van de organisatie waar men werkzaam is en de eigen opleidingsmogelijkheden daarbinnen. Tevens wordt naar de mening gevraagd over de gevolgde bijscholing.

\section{Achtergrondvariabelen:}

In de enquête wordt naar een aantal algemene achtergrondvariabelen gevraagd, zoals leeftijd, vooropleiding, e.d. Ook is bekend hoe lang men reeds werkzaam is bij de betreffende organisatie.

Publikatie:

Ministerie van Sociale Zaken en Werkgelegenheid (1990), Evaluatie Experiment Intensivering Bijscholing, VUGA Uitgeverij, 's-Gravenhage.

Bestanden evaluatie scholingsmaatregelen

Beheer: Nederlands Economisch Instituut, Rotterdam

Toegankelijkheid: Niet beschikbaar

Doelgroep: Deelnemers C(A)VV, CBB, KRS

Steekproef: $\quad$ Ongeveer 400

Korte beschrijving van het bestand:

De bestanden zijn opgezet in het kader van evaluatie-onderzoek naar de effecten van de scholingsmaatregelen van het Ministerie van Sociale Zaken en Werkgelegenheid. De enquêtes zijn gehouden onder de deelnemers aan de cursussen bij de C(A)VV (Centra voor (Administratieve) Vakopleiding van Volwassenen), CBB (Centra voor Beroepsoriëntatie en Beroepsbeoefening) en de KRS (KaderRegeling Scholing). Bovendien is voor deze evaluatieonderzoeken een controlegroep samengesteld.

Variabelen met betrekking tot volwasseneneducatie:

In de enquête worden de gangbare vragen over cursusdeelname gesteld, zoals de richting en de 'normale' duur van de cursus. Aan de respondenten wordt bovendien gevraagd hoeveel uur per week zij aan de cursus hebben besteed, wat het resultaat van de cursus is (helemaal afgemaakt of voortijdig gestopt) en of men inmiddels werk heeft gevonden.

Achtergrondvariabelen:

Naast leeftijd, geslacht en niveau van de vooropleiding is ook de werkloosheidsduur aan het begin van de gevolgde cursus bekend. Ook is gevraagd naar het aantal sollicitaties in de periode voorafgaand aan de cursus. 
Publikaties:

Koning, J. de, M. Koss, A. Verkaik (1987), De arbeidsmarkteffecten van het centrum voor (administratieve) vakopleiding van volwassenen, Eerste deelrapport, Ministerie van Sociale Zaken en Werkgelegenheid, 's-Gravenhage.

Koning, J. de, P.J. van Nes (1989), Landelijke evaluatie kaderregeling scholing, Stichting het Nederlands Economisch Instituut, Rotterdam

Project Onderwijs, Scholing en Arbeidsmarkt in de Metaalnijverheid (OSAM)

Beheer: OSAM-onderzoeksteam/RISBO

Toegankelijkheid: Beschikbaar voor onderzoeksdoeleinden

Korte beschrijving van het bestand:

Er wordt een aantal deelbestanden onderscheiden met elk een eigen doelgroep, zoals bijvoorbeeld leerlingen en ex-leerlingen КМBO, leerlingwezen en Middelbaar Technisch Onderwijs, cursisten en ex-cursisten CVV, CBB en PBVE, maar ook werkgevers. De steekproefomvang varieert van 44 (kandidaat-cursisten CVV) tot 1.839 (werknemers inzake uitstroomonderzoek). De surveys hebben een cross-sectie karakter, met uitzondering van het bestand met betrekking tot het beroepsgericht onderwijs, waarbij twee metingen zijn verricht.

Variabelen met betrekking tot volwasseneneducatie:

Bij de werkgeverssurveys wordt gevraagd naar het scholingsbeleid van de bedrijven, de deelname van hun werknemers aan cursussen en trainingen en de behoefte aan cursussen (naar soort). Bij de surveys onder de (ex-)cursisten wordt onder andere gevraagd naar de cursussen die zijn gevolgd na het afsluiten van de reguliere opleiding (aantal, soort, wel/geen diploma). Ook de motieven voor deelname en het intern rendement van de cursus zijn bekend.

\section{Achtergrondvariabelen:}

Op bedrijfsniveau worden onder andere de volgende achtergrondvariabelen verzameld: branche, bedrijfsomvang, omzet, technologische ontwikkeling en personeelsontwikkeling. De achtergrondvariabelen op individueel niveau betreffen onder andere leeftijd, geslacht, nationaliteit, vooropleiding, beroep, opleiding vader/moeder en de werkloosheidsduur.

Publikatie:

Diverse publikaties van het Rotterdams Instituut voor Sociologisch en Bestuurskundig Onderzoek (RISBO), Erasmus Universiteit Rotterdam. 
Beheer: $\quad$ Economisch Instituut voor de Bouwnijverheid

Toegankelijkheid: Niet beschikbaar

Doelgroep: Werknemers geregistreerd bij het Sociaal Fonds Bouwnijverheid

Steekproef: $\quad$ Circa 1.000 personen

Korte beschrijving van het bestand:

Van 1980-1989 heeft dit onderzoek een panelkarakter. Vanaf 1990 hebben de gegevens echter betrekking op een aselecte steekproef uit de genoemde doelgroep.

Variabelen met betrekking tot volwasseneneducatie:

Aan de respondenten wordt gevraagd of zij, terwijl ze reeds werkzaam waren in de bouwsector, een vakopleiding hebben gevolgd, bijvoorbeeld een opleiding van de Stichting Vakopleiding Bouwbedrijf (SVB), het KMBO of interne bedrijfsopleidingen. Bovendien is bekend of men de gevolgde cursussen heeft afgemaakt, voortijdig heeft beëindigd of dat men nog met de cursus bezig is. Tenslotte wordt ook naar de behoefte aan bijscholing gevraagd en de mate waarin het bedrijf aan bijscholing doet.

Achtergrondvariabelen:

Het bestand bevat een aantal achtergrondvariabelen betreffende het werkverleden in de bouw, alsmede een aantal gegevens over de huidige werkzaamheden. Ook zijn de vooropleiding en de leeftijd van de respondenten bekend.

Publikatie:

Aartman, J.A.G. (1990), De bouwarbeidsmarkt in het najaar van 1989, Economisch Instituut voor de Bouwnijverheid, Amsterdam.

OSA arbeidsaanbodsurvey 1988

Beheer: Stichting Organisatie voor Strategisch Arbeidsmarktonderzoek, 's-Gravenhage Toegankelijkheid: Met toestemming OSA

Doelgroep: Personen tussen 18 en 65 jaar, exclusief scholieren/studenten en militair dienstplichtigen

Steekproef: $\quad 4.464$ personen

Korte beschrijving van het bestand:

Het OSA-arbeidsaanbodsurvey heeft een panelkarakter, waarvan de derde ronde is gehouden in 
het najaar van $1988^{7}$. In het najaar van 1990 heeft een vierde enquêteronde plaatsgevonden. De gegevens hiervan zijn echter nog niet beschikbaar.

Variabelen met betrekking tot volwasseneneducatie:

De respondenten is gevraagd welke opleidingen of cursussen zij na de lagere school hebben gevolgd. Van deze opleidingen/cursussen zijn dan het niveau en de richting, ingedeeld volgens de Standaard Onderwijs Indeling 1978, bekend. Bovendien is de respondenten gevraagd of men al dan niet alle leerjaren heeft doorlopen, of er een akte, diploma of getuigschrift is behaald en wanneer men de opleiding heeft beëindigd. Door deze data te combineren met de gegevens over de hoogst gevolgde en afgesloten dagopleiding kan worden nagegaan welke opleidingen/ cursussen moeten worden getypeerd als 'volwasseneneducatie'. Van de tussen september 1986 en september 1988 gevolgde cursussen is tevens bekend of deze door het bedrijf waar men werkt zijn georganiseerd of door het individu op eigen initiatief zijn gevolgd. Tenslotte is van de respondenten bekend of zijn op het moment van enquête aan een cursus deelnamen.

Achtergrondvariabelen:

De OSA-enquête bevat een groot aantal achtergrondvariabelen, zoals geslacht, leeftijd (geboortedatum) en nationaliteit. Ook zijn er een groot aantal gegevens bekend over de initiële opleiding (niveau en richting) en de arbeidsmarktsituatie (bijvoorbeeld werkend of niet-werkend en, indien wel werkend, in welk beroep en bedrijfssector) van de respondenten.

Publikatie:

Allaart, P.C., R. Kunnen, H.A. van Stiphout (1989), Trendrapport Arbeidsmarkt 1989, OSAvoorstudie V32, 's-Gravenhage.

\section{Brabant-survey}

Beheer: $\quad$ Universiteit van Amsterdam, vakgroep micro-economie

Toegankelijkheid: In overleg

Doelgroep: Schoolverlaters lagere school (6 $\quad$ klas) 1953

Steekproef: Ongeveer 2.800

Korte beschrijving van het bestand:

Onder de schoolverlaters van de lagere school (1953) is 30 jaar later een enquête gehouden, waarin hen onder andere is gevraagd naar hun ervaringen met het onderwijs en op de

7. De eerste twee enquêteronden zijn respectievelijk gehouden in het voorjaar van 1985 en het najaar van 1986. 
arbeidsmarkt.

Variabelen met betrekking tot volwasseneneducatie:

Aan de respondenten is (retrospectief) gevraagd aan welke opleidingen of cursussen zij na het verlaten van de lagere school hebben deelgenomen, dat wil zeggen inclusief de volwasseneneducatie-opleidingen. Van deze cursussen is naast het niveau en de richting (gecodeerd volgens SOI) de begin- en einddatum bekend.

\section{Achtergrondvariabelen:}

Naast de gebruikelijke variabelen als leeftijd en geslacht en dergelijke is van de respondenten de gehele opleidingsloopbaan bekend. Bovendien is een aantal vragen gesteld over de werkkring waarin men op het moment van enquête werkzaam (1983) was.

Publikatie:

Hartog, J., G. Pfann (1985), Vervolgonderzoek Noord-Brabantse $\sigma^{e}$ klassers, Universiteit van Amsterdam.

Van jaar tot jaar $4^{e}$ fase

Beheer: $\quad$ ITS, Nijmegen; SVO, 's-Gravenhage

Toegankelijkheid: Nog niet toegankelijk ${ }^{8}$

Doelgroep: $\quad$ Schoolverlaters lagere school (6 $6^{\mathrm{e}}$ klas) 1965

Steekproef: $\quad 1.192$ personen

Korte beschrijving van het bestand:

Het onderzoek Van jaar tot jaar betreft een longitudinaal onderzoek onder de bovengenoemde doelgroep. De vierde enquêteronde heeft plaatsgevonden in december 1987. De eerste ronde is gehouden in 1965/1966.

Variabelen met betrekking tot volwasseneneducatie:

Van de respondenten is de feitelijke onderwijsdeelname (waaronder de volwasseneneducatie) gedurende de gehele loopbaan bekend. Dit betreft zowel niveau als richting van de gevolgde opleidingen. Tevens is gevraagd naar de plannen met betrekking tot cursusdeelname en de motivatie om al dan niet aan cursussen deel te nemen.

8. De eerste drie fasen van het onderzoek zijn wel toegankelijk via het Steinmetz-archief. 
Achtergrondvariabelen:

Het bestand bevat een groot aantal achtergrondvariabelen. Naast de gebruikelijke, zoals leeftijd, geslacht, vooropleiding e.d., betreft dit bijvoorbeeld de gehele beroepsloopbaan. Bovendien zijn een groot aantal 'subjectieve kenmerken' (waarden en houdingen) van de individuen bekend

\section{Publikatie:}

In voorbereiding, verschijnt voorjaar 1991. 


\section{NABESCHOUWING EN CONCLUSIES}

In het voorafgaande hoofdstuk is een groot aantal databestanden beschreven die inzicht verschaffen in de werking en het functioneren van de markt voor volwasseneneducatie in Nederland. De vraag dringt zich op of de nu reeds beschikbare gegevens het gehele terrein van de volwasseneneducatie dekken of dat er nog bepaalde 'gaten' zijn. Anders geformuleerd: welke onderzoeksvragen kunnen met de huidige onderzoeksbestanden worden beantwoord en voor welke vragen zou aanvullende dataverzameling noodzakelijk zijn?

Om deze vraag goed te kunnen beantwoorden is het nodig om een overzicht te hebben van alle mogelijke onderzoeksvragen die met betrekking tot de werking van de markt van volwasseneneducatie kunnen worden gesteld. Vervolgens zou dan kunnen worden nagegaan in hoeverre deze onderzoeksvragen met behulp van de bestaande databronnen kunnen worden beantwoord. Het maken van een dergelijk uitputtend overzicht valt echter buiten het kader van deze studie. Het hierna volgende overzicht moet daarom eerder worden beschouwd als een aanzet daartoe. $\mathrm{Er}$ is geprobeerd een schema te ontwikkelen waarbinnen de verschillende soorten onderzoeksvragen ondergebracht kunnen worden. Daarbij is niet gestreefd naar volledigheid: het schema heeft uitsluitend betrekking op vragen rondom de marktwerking; andere beleidvragen op het terrein van volwasseneneducatie vallen daar buiten.

Het voordeel van een dergelijk schema is dat snel inzicht kan worden verkregen in eventuele 'blinde vlekken'. De mogelijke onderzoeksvragen zijn ingedeeld in vijf niveaus: het niveau van het individu, het niveau van de organisatie, het niveau van de opleiding, het (deel-)marktniveau en het macro-niveau. Per niveau worden drie mogelijke onderzoeksaspecten onderscheiden: de scholingsbehoefte en de deelname aan scholing, de kosten en het intern rendement, en de effecten van de scholing.

Hieronder zal per aspect, bij wijze van illustratie, een aantal mogelijke onderzoeksvragen worden geformuleerd. Sommige van deze vragen kunnen op meerdere niveaus worden gesteld. Vervolgens zal globaal worden aangegeven in hoeverre de eerder beschreven databronnen de informatiebehoefte op dit punt dekken. In een aantal gevallen is aanvullende informatie beschikbaar uit andere bronnen. Het betreft hier met name overige CBS-statistieken, CPBpublikaties, de databank voor het technologiebeleid 'METING' van het Ministerie van Economische Zaken ${ }^{9}$, het geautomatiseerde informatiesysteem op het gebied van studie en beroepskeuze I-See! van het Landelijk Dienstverlenend Centrum (LDC) en het Informatiesysteem

9. Ministerie van Economische Zaken (1990), Meting 2; Indicatoren voor technologische positiebepaling van Nederland, 's-Gravenhage. 
Onderwijs-Arbeidsmarkt ${ }^{10}$ van het Researchcentrum voor Onderwijs en Arbeidsmarkt.

Individueel niveau

1. Deelname en scholingsbehoefte

Wat is de scholingsbehoefte van volwassenen, zowel qua inhoud als qua vormgeving? Hoeveel mensen nemen deel aan de verschillende vormen van volwasseneneducatie? Wat is het karakter van deze scholing? Wat zijn de achtergrondkenmerken van de deelnemers? Wat zijn de motieven voor deelname? Is de scholingsmarkt transparant genoeg voor individuen? etc.

Over de feitelijke deelname is vrij veel bekend. De belangrijkste databronnen zijn EBB en de CBS-statistieken over deelname aan regulier deeltijdonderwijs en bedrijfsopleidingen. Over de scholingsbehoefte worden niet systematisch gegevens verzameld, behalve voor de bouwsector (trendanalyse van feitelijke deelnamecijfers kan hier wel enig inzicht in verschaffen). Achtergrondkenmerken van de deelnemers zijn te achterhalen via TBO, AVO, EBB en de longitudinale onderzoeken (met name het OSA-panel). Over de motieven van deelname is uitsluitend iets bekend bij deelpopulaties (OU, PBVE). Er is niets bekend over de transparantie van de scholingsmarkt.

\section{Kosten en intern rendement}

Wat zijn de (directe en indirecte) kosten voor deelname? Hoeveel mensen lopen vertraging op tijdens de opleiding of verlaten de opleiding voortijdig? Met welke persoonskenmerken hangt dit samen? etc.

De hoogte van het cursusgeld kan worden achterhaald via de opleidingen zelf en (deels) via ISee!. Gegevens over intern rendement (vertraging, uitval) zijn uitsluitend bekend voor specifieke deelbestanden (OU, PBVE, scholingsmaatregelen Arbvo).

\section{Effecten}

Wat is het effect van de opleiding op de beroepsloopbaan (verkrijgen van werk, niveau functie, inkomen)? Wat is het effect van het voortijdig afbreken van de opleiding? etc.

Over de effecten van scholing is weinig bekend. Informatie hierover kan uitsluitend ontleend worden aan de longitudinale bestanden (OSA, Brabant-survey, Van Jaar tot Jaar) en - voor een specifieke populatie - de evaluatie-studies van het NEI.

10. Zie ROA (1990), Het informatiesysteem onderwijs-arbeidsmarkt; onderzoekprogramma 1990/1991, ROA-R-1990/4, Maastricht. 


\section{Organisatieniveau}

\section{Deelname en scholingsbehoefte}

Wat is de scholingsbehoefte van individuele arbeidsorganisaties? Hoeveel arbeidsorganisaties participeren in bedrijfsopleidingen? Wat is het aandeel van het personeel dat hierbij is betrokken en welke soort functies betreft het vooral? Wat zijn de achtergrondkenmerken van de betreffende arbeidsorganisaties? Welke rol spelen bedrijfsopleidingen in het personeels- c.q. loopbaanplanningbeleid van de arbeidsorganisaties? Is de scholingsmarkt transparant genoeg voor arbeidsorganisaties? etc.

Informatie over de feitelijke deelname kan verkregen worden via het onderzoek van het CBS naar bedrijfsopleidingen in Nederland. Over de scholingsbehoefte worden niet systematisch gegevens verzameld (de metaalsector vormt hierop een uitzondering). Informatie over de achtergrondkenmerken van de betreffende bedrijven zijn deels beschikbaar via het CBSonderzoek naar bedrijfsopleidingen. Daarnaast is informatie beschikbaar via het OSAarbeidsvraagsurvey. Er zijn geen gegevens over de transparantie van de scholingsmarkt.

\section{Kosten en intern rendement}

Welk deel van de totale loonsom investeren arbeidsorganisaties in de scholing van hun personeel? Welke knelpunten ondervinden ze bij de uitvoering van scholingsplannen (bijvoorbeeld problemen bij vervanging)? Hangt dit samen met achtergrondkenmerken van de betreffende organisaties? etc.

$\mathrm{Er}$ is informatie beschikbaar over de opleidingskosten (CBS-bedrijfsopleidingen). Daarentegen ontbreekt systematische informatie over mogelijke knelpunten.

\section{Effecten}

Wat is het effect van scholing op het functioneren van de arbeidsorganisaties (bijvoorbeeld innovatief vermogen, kwaliteit van produkten of dienstverlening, winst, flexibiliteit, produktiviteit)? etc.

Informatie hierover ontbreekt nog volledig, maar kan in beginsel beschikbaar komen bij toekomstige ronden van de OSA-arbeidsvraagsurvey.

\section{Opleidingsniveau}

1. Deelname en scholingsbehoefte

Welke opleidingen worden aangeboden? Sluit het bestaande scholingsaanbod aan bij de 
scholingsbehoeften van zowel individuen als arbeidsorganisaties? Op welke terreinen ontbreken opleidingstrajecten of moeten opleidingen worden aangepast? Wordt door de opleidingen de beoogde doelgroepen bereikt? etc.

Systematische informatie over het opleidingsaanbod is voor een belangrijk deel bekend via ISee!. $\mathrm{Er}$ is geen informatie beschikbaar over de aansluiting van het aanbod bij de scholingsbehoefte. Of de doelgroepen worden bereikt is alleen voor specifieke populaties na te gaan (OU, PBVE, Arbvo).

\section{Kosten en intern rendement}

Wat zijn de opleidingskosten per leerling voor de verschillende opleidingen? Hoe groot is de leerling-leerkracht ratio? etc.

Informatie hierover kan verkregen worden voor het reguliere deeltijdonderwijs door gegevens uit verschillende databronnen te combineren (CBS-statistieken, begrotingen van het Ministerie van Onderwijs en Wetenschappen, Arbvo).

\section{Effecten}

Welke volwasseneneducatie-programma's zijn succesvol (tevredenheid deelnemers, tevredenheid arbeidsorganisaties, verloop, bereiken van doelstelling)? Voor wie zijn ze succesvol? Over welke kenmerken beschikken deze programma's? etc.

Informatie hierover is in beperkte mate beschikbaar voor deelpopulaties (OU, PBVE, Arbvo).

\section{(Deel-)marktniveau}

\section{Deelname en scholingsbehoefte}

Wat is het effect van technologische ontwikkelingen op de vereiste kwalificaties en welke (toekomstige) scholingsbehoefte vloeit hier uit voort? In welke sectoren van de arbeidsmarkt doen zich overschotten respectievelijk tekorten voor en welke (toekomstige) scholingsbehoefte vloeit hier uit voort? Worden in een sector collectieve scholingsafspraken gemaakt? Hoe groot is de scholingsintensiteit en de spreiding van scholing binnen een sector? etc.

Systematische informatie over de toekomstige scholingsbehoefte is op dit moment alleen op landelijk niveau beschikbaar via het Informatiesysteem Onderwijs-Arbeidsmarkt van het ROA. Informatie over scholingsafspraken is beschikbaar via de databank 'METING' van EZ. Informatie over scholingsintensiteit en de spreiding daarvan is beschikbaar via het CBS-onderzoek naar bedrijfsopleidingen. 
2. Kosten en intern rendement

Wat zijn de kosten die gemoeid zijn met collectieve scholingsafspraken? Hoe groot is het produktiviteitsverlies als gevolg van scholing? etc.

De kosten die gemoeid zijn met collectieve scholingsafspraken kunnen achterhaald worden via 'METING'. Over het produktiviteitsverlies kunnen slechts indicaties worden verkregen worden via het CBS-onderzoek naar bedrijfsopleidingen.

\section{Effecten}

Wat is het effect van scholing op het mobiliteits- en flexibiliteitspotentieel van individuen en bedrijven in de deelmarkt? Wat is het effect van scholing op de economische groei en het innovatief vermogen van een sector? etc.

In beginsel is een aantal effectmaten van scholing op het niveau van de sector (economische groei, technologische ontwikkelingsgraad, mobiliteit) beschikbaar via CBS-statistieken, CPBpublikaties, 'METING', en het Informatiesysteem Onderwijs-Arbeidsmarkt. Een probleem hierbij zal vooral zijn om voldoende lange tijdreeksen te construeren.

\section{Macro-niveau}

\section{Scholingsbehoefte en deelname}

Worden scholingsmogelijkheden op een evenredige wijze verdeeld over de verschillende aanbodcategorieën, of blijven bepaalde groepen (bijvoorbeeld langdurig werklozen, laag opgeleiden, etnische minderheden) systematisch verstoken van verdere kwalificering (verdelingsproblemen)? Zijn opleidingstrajecten voldoende op elkaar afgestemd of zijn er belemmeringen in de doorstroming? Wat betekent dit voor de inrichting van het initieel onderwijs? etc.

Informatie over de verdelingsproblematiek is redelijk beschikbaar via EBB, AVO, TBO, OSAarbeidsaanbodsurvey en - voor deelpopulaties - via OU, PBVE en Arbvo. Over de afstemming van opleidingstrajecten onderling, alsmede over de afstemming tussen initieel onderwijs en volwasseneneducatie is geen systematische informatie bekend.

\section{Kosten en intern rendement}

Welk deel van het nationaal inkomen wordt besteed aan scholing voor volwassenen, zowel in de publieke sfeer (scholingsmaatregelen) als de private sfeer (individuen en bedrijven)? etc.

Informatie hierover is deels beschikbaar via het CBS-onderzoek naar bedrijfsopleidingen, deels 
zal de informatie gevonden moeten worden door gegevens uit verschillende databronnen te combineren (CBS-statistieken, begrotingen van O\&W en Arbvo).

\section{Effecten}

Wat is het effect van scholing op de groei van de werkgelegenheid, het bestrijden van de werkloosheid, het verhogen van de participatiegraad, de economische groei, de internationale concurrentiepositie, de technologische ontwikkeling etc.?

Hiervoor geldt hetzelfde als hierboven is vermeld is bij het niveau van de (deel-)markt. In beginsel is een aantal effectmaten van scholing op macro-niveau beschikbaar via CBSstatistieken, CPB-publikaties, de databank 'METING' en het Informatiesysteem OnderwijsArbeidsmarkt. Een probleem zal echter zijn om voldoende lange tijdreeksen te construeren.

Schematisch zou men het bovenstaande als volgt kunnen weergeven.

Schema 1. De aanwezigheid van data met betrekking tot volwasseneneducatie

$\begin{array}{lll}\text { Niveau } & \text { Keelname Effecten }\end{array}$

$\begin{array}{ll}\begin{array}{ll}\text { Individueel niveau } \\ \text { Organisatieniveau }\end{array} & + \\ \text { Opleidingsniveau } & \\ \text { (Deel-)marktniveau } & 0 \\ \text { Macro-niveau } & 0 \\ & \\ & \end{array}$

Voor alle onderscheiden cellen geldt dat de beschikbare informatie niet voldoende is om alle vragen op dit gebied te beantwoorden. In dat opzicht is de informatievoorziening op de meeste fronten voor verbetering vatbaar. Met name op het terrein van de effecten van scholing blijken de bestaande informatiebronnen echter tekort te schieten. Informatie over de scholingseffecten is ofwel helemaal afwezig (op het niveau van de organisatie), of slechts summier aanwezig (op het niveau van het individu en de opleiding). Op meso- en macro-niveau ontbreken voldoende lange tijdreeksen om de effecten van scholing te kunnen bestuderen. De conclusie luidt daarom 
$-23-$

dat additionele dataverzameling zich in eerste instantie moet richten op de effecten van scholing. Daarnaast zouden in ieder geval additionele data moeten worden verzameld over het intern rendement van de opleiding (uitval, vertraging). 


\section{BIJLAGE: LIJST MET GERAADPLEEGDE INSTANTIES}

Bureau Berenschot (dhr. Dingemans)

Bureau Bartels (dhr. van Veen)

CBS (dhr. Brand)

EIB (dhr. Bremer)

ITS (dhr. Diederen, dhr. Hövels)

IVA (dhr. van Dongen)

Ministerie van Sociale Zaken en Werkgelegenheid (dhr. Boot, dhr. Flaman)

Ministerie van Onderwijs en Wetenschappen (dhr. van den Dool)

NEI (dhr. de Koning)

Open Universiteit (mevr. Joosten)

OSA (dhr. Vosse)

Rijksuniversiteit Groningen/RION (mevr. Bosman, dhr. van der Kamp)

RISBO (dhr. Nieuwenhuis)

RVE (mevr. Cramer)

SCO (dhr. Wilbrink)

SCP (mevr. Bronneman-Helmers)

SEO (dhr. Teulings)

Technische Universiteit Twente/OCTO (dhr. Mulder)

Universiteit van Amsterdam, vakgroep micro-economie (dhr. Groot, dhr. Hartog) 